\title{
Introdução Histórica ao Estudo das Soluções Pacíficas de Litígios e das Arbitragens Comerciais Internacionais.
}

\author{
Guido F. S. Soares \\ Professor Assistente-Doutor do Departamento de \\ Direito Internacional da Faculdade de Direito da \\ Universidade de são Paulo e do Departamento de \\ Politica da Puc-SP.
}

Desde a mais remota antigüidade, os litígios entre grupos humanos nem sempre foram resolvidos pela força, cuja maior demonstração têm sido as guerras, assim como as pendências entre homens de um mesmo grupo social nem sempre tiveram solução mediante o recurso aos órgãos judicantes. Mesmo em tempos onde não se cogitava da existência de um direito internacional, muitas das formas de soluções pacíficas de litígios entre grupos sociais já tinham aparecido.

A doutrina costuma afirmar que, nas contendas entre as primitivas tribos, existiriam procedimentos pacíficos tais como a mediação e a arbitragem. Na base da especulação sobre as possíveis soluções de contendas entre Egito, Kheta, Assíria e Babilônia, supõe-se que a mediação fosse empregada, citando-se, mesmo, um caso de arbitragem entre cidadesEstados da Babilônia, cerca do ano 3.000 a.C.. Ainda no Oriente antigo, menciona-se o caso dos hebreus, que, na câmara composta de três árbitros, a Beth-Din, resolviam todas as pendências de direito privado, pela via arbitral. 
Se, no dizer de Laurent, "a sociedade dos deuses é o reflexo da sociedade dos homens ${ }^{1}$, bastaria examinar o comportamento daqueles para ter-se uma idéia de que a arbitragem internacional, em especial, nos litígios de fronteiras, teve grande importância na Grécia antiga. Os próprios autores gregos referem ao fato de a arbitragem reportar-se aos tempos míticos, quando os litígios entre deuses e heróis eram resolvidos por um laudo arbitral proferido por um dos pares: Zeus é eleito juiz entre Atenê e Posseidon a propósito de Egina, Foronê exerce o mesmo papel entre Hera e Posseidon a propósito da Argólida $^{2} \mathrm{Na}$ história mitológica da Grécia, em várias ocasiōes os deuses aparecem como mediadores entre rivais e, "em seguida a alguma aliança firmada entre duas urbes, se representavam as suas divindades por estátuas ou medalhas dandose as mãos ${ }^{3}$. Conforme Foustel de Coulanges, "quando os deuses eram inimigos, havia guerras, sem piedade nem regras, mas quando amigos, logo os homens ficavam mutuamente ligados entre si e selavam esse sentimento de amizade com deveres recíprocos ${ }^{4}$

$\mathrm{Na}$ verdade, se as soluções pacíficas puderam existir na Grécia antiga foi porque existiu a possibilidade de haver deuses comuns a várias cidades, portanto valores comunitários mais amplos, o que de fato aconteceu, na medida em que se firmou uma religião pan-helênica e se criou um verdadeiro direito internacional. Se cada urbe tinha seu deus epônimo, os deuses do Olimpo, comuns a toda Grécia, protegeriam qualquer grego nas relações dentro do mundo grego e lhe forneceriam os meios para as soluções pacíficas das contendas com um idivíduo pertencente à mesma comunidade de valo-

1. Apud MrCHEL DE TAUBE, Les Origenes de l'Arbitrage International; Antiqueté et Moyen Age, in Recueil des Cours da Academia de Direito Internacional de Haia, 1932, v. IV, t. 42. Citaçóes livremente traduzidas pelo autor.

2. TAUBE, id., p. 15 .

3. Foustel de Coulanges, A Cidade Antiga, Estudo sobre o Culto, o Direito $e$ as Instituiçōes da Grécia e de Roma, 10 a. Ed. Livraria Clássica Editora, Lisboa, 1971, p. 260 (trađuçăo e glossário de Fernando de Aguiar).

4. Coulanges, id., p. 261. 
res. Por outro lado, à medida em que a situação do estrangeiro se abranda, as soluções por meio de negociações, bons ofícios e arbitragens se tornam freqüentes. A doutrina aponta precisamente o nascimento do Direito Internacional Privado na Grécia antiga, à medida em que nos tratados de paz ou de comércio se inseriam cláusulas de "estimulações de não cometer injustiça" ou "para não mais praticar atos arbitrários" 5 , em benefício dos cidadãos da outra parte contratante.

Em etapa posterior, dada a similitude dos estatutos municipais, criou-se na Grécia uma isopolitéia, ou seja, "o reconhecimento, por tratado internacional, da igualdade de direitos civis entre cidadãos das partes contratantes, o que lhes conferiria todos os direitos dos autoctones no domínio do direito de família, de propriedade, de contratos (relativos à indústria, comércio e agricultura), com imunidades alfandegárias, etc., em resumo, quase toda a esfera dos direitos civis dos cidadãos, com exceção dos direitos políticos ${ }^{6}$. Em outros tratados internacionais, chegou-se a estabelecer uma igualdade completa entre os cidadãos, sympolitéia, inclusive de direitos políticos; contudo, foram exemplos raros, segundo TAuBE. Criava-se, assim, um sistema de direito uniforme comum a toda Grécia (koinós nomós), susceptível de transpor para as relações intermunicipais, as práticas de soluções arbitrais já existentes no interior das cidades. No dizer de TAUBE, "a instituição dos diaitetai, árbitros públicos para contendas privadas, em Atenas, devia, por exemplo, suscitar cedo ou tarde, imitações na esfera das relações de Estado a Estado ?

No domínio das relações públicas, os mais antigos tratados contêm cláusulas compromissórias, a exemplo, o tratado de paz concluído em 445 a.C., entre Esparta e Antenas. No Tratado de Nícias, conservado por Tucídides, lê-se: "Não será mais permitido aos lacedemônios e a seus aliados, de fazer

\footnotetext{
5. TAUBE, id., p. 32.

6. TAUBE, id., p. 36 .

7. TAUBE, $i d .$, p. 37.
} 
a guerra aos atenienses e a seus aliados... sob qualquer pretexto". "A mesma proibição é feita aos atenienses e seus aliados, com respeito aos lacedemônios e seus aliados". Se surgir um litígio entre eles, submeterão a solução do caso a um procedimento de direito conforme os princípios sob os quais se deverão colocar de acordo ${ }^{8}$.

Nas relações particulares, mesmo com o aperfeiçoamento do julgamento por funcionários investidos do poder judicante pela autoridade política, o procedimento arbitral coexistiu com o processo judicial, até o Século II a.C. (dominação romana). TAube observa que, em grego clássico, há dois verbos, um para designar o julgamento arbitral, suavisar uma contenda (dialúein) e outro, para o julgamento por juízes togados, resolver por julgamento (diakrínein).

A base jurídica da arbitragem entre particulares ou entre cidades gregas era um compromisso, contrato especial, ou uma cláusula compromissória inserta nos contratos ou tratados de comércio, de aliança ou de paz. O direito aplicável era o "direito comum dos Helenos", como já se referiu, intermunicipal, verdadeiro germe de um direito internacional. Os juízes arbitrais eram escolhidos pelas partes e poderiam ser tanto um rei, um magistrado, um homem público qualquer; por vezes aparecem instituições religiosas como o Conselho Anfictiônico ou o Oráculo de Delfos. Muitas vezes era escolhido, em razão de seu conhecimento e especialização em relações intermunicipais, algum proxena, cidadão de importância, que representava os interesses dos estrangeiros residentes na cidade (e por tal razão, é considerado como o antecessor histórico dos modernos cônsules) A sentença arbitral, quando prolatada em assuntos intermunicipais, era, à semelhança dos tratados, gravada em muros de templos, em estelas ou no sopé de estátuas, razões por que há abundantes informações sobre a prática da arbitragem intermunicipal na Grécia antiga.

8. apud TAUBE, id., p. 40 . 
Quanto à execução das sentenças arbitrais, TAUBE afirma que, na prática, se conhecem vários exemplos de execução espontânea, bona fide, e cita o mais famoso: "a disputa entre Atenas e Megara a respeito da ilha de Salamina... que, segundo a tradição teria sido decidida pela arbitragem de cinco juízes espartanos, cerca do ano 600 , não reaparece em cena senão o final do Século IV, apesar da importância do objeto do litígio para os habitantes de Megara; assim, a partir dessa época, Salamina permanece em mãos dos atenienses; Megara se teria, por conseguinte, inclinado diante da sentença ${ }^{9}$.

A prática da arbitragem na Grécia antiga, mesmo após a dominação romana do Século II a.C., continuou, para resolver os conflitos de fronteiras entre cidades. TAUBE aponta o paradoxo de, pela pax romana, apesar da política imperialista dos romanos, terem estes permitido a sobrevivência na Grécia de antigos usos de recurso à arbitragem em desavenças entre cidades autônomas e, acrescenta aquele autor, tal fato é mais uma prova da política de Roma de permitir uma diversidade na unidade.

Quanto a Roma, o procedimento de arbitragens para resolver disputas que hoje seriam internacionais, era totalmente incompatível com seu espírito de dominação imperialista. Contudo, sua contribuição para a arbitragem entre particulares é da mais alta importância, pois aperfeiçoou o instituto e legou aos pósteros os grandes princípios de direito, que permitiriam fundarem-se no moderno direito internacional os institutos para soluçōes pacíficas de litígios entre particulares e entre Estados.

Com efeito, a arbitragem entre particulares era considerada um procedimento de base contratual e tratada como um ato de natureza pactícia, nas várias fases do direito romano; as partes tinham liberdade de assinar um compromisso em que estipulavam o respeito à decisão dos árbitros e, nos con-

9. TАUBE, id., p. 46 . 
tratos, podiam instituir cláusulas compromissórias. $\mathrm{O}$ compromissum, no período clássico, já era considerado um pacto legítimo, ou seja, válido nele mesmo, independentemente de estar vinculado a outro pacto que lhe determinasse a validade.

Para fazer respeitar o compromisso ou a cláusula compromissória, o pretor concedia uma ação, arbiter in causis bonae fidei. No caso de haver estipulação de penalidade inserida no compromisso ou no contrato, stipulatio poenae, havia a ação conditio ob rem dati re non secuta, para a restituição da soma devida pela parte que não permitisse a constituição do juízo arbitral e recorresse à jurisdição togada. Em qualquer julgamento arbitral, o pretor impunha a obrigação ao árbitro de aceitar julgar a controvérsia, receptum arbitri. A sentença era irrecorrível aos tribunais, inexistindo, contudo, meios legais de compelir o seu cumprimento.

$\mathrm{O}$ árbitro decidia sem submeter-se a qualquer lei, portanto sem a obrigatoriedade das fórmulas rituais. Pode-se imaginar a importância de tal fato para o desenvolvimento e a democratização da própria justiça togada, ao se levar em conta que as fórmulas eram nos primeiros tempos do direito romano, absolutamente rígidas e, se o autor ou réu as pronunciasse erroneamente, não teriam suas pretensões acolhidas, mesmo que houvesse flagrante iniquiidade. "Quando troca certa palavra por outra, a lei deixa de existir e já não o pode defender... Gaio narra a história de certo homem a quem o vizinho havia cortado as vinhas; o fato era verdadeiro e o homem pronunciou a lei, mas como, onde a lei dizia árvores, o homem nomeasse videiras, logo perdeu a questão (Institutas, IV, II $)^{10}$. Por outro lado, o direito romano dessa época era de cunho eminentemente religioso e, portanto, guardava o seu caráter de ser revelado unicamente aos iniciados; "canto sagrado e misterioso, a repetir-se de idade em idade com piedoso respeito, que só os sacerdotes escreviam e apenas os ho-

10. apud Coulanges, id., p. 236. 
mens das famílias religiosas podiam conhecer ${ }^{11}$, era um privilégio dos que guardavam as tradições. Sem dúvida, o caráter informal do procedimento arbitral, muito deve ter contribuído para quebrar a primitiva rigidez do processo romano, ao elaborar soluções mais pragmáticas do que as fórmulas da lei.

Ao tempo de Cícero, este poderia distinguir o juízo arbitral do juízo togado da seguinte forma, no Pro Roscio Comoedo: "uma coisa é um julgamento, outra uma arbitragem... vêm-se a julgamento para perder ou para ganhar todo o processo, tomam-se árbitros com a intenção de não perder tudo ou não ganhar tudo ${ }^{12}$. $\mathrm{Na}$ mesma ordem de considerações, Seneca, no De Beneficiis, afirmaria que "quando uma causa é boa, prefere-se um juiz a um árbitro, porque o primeiro é sujeito à forma e circunscrito pelos limites que não pode ultrapassar, ao passo que o segundo é livre e sem liames ${ }^{13}$.

$\mathrm{O}$ instituto se aperfeiçoou com a prática e, durante o Baixo Império, Justrniano legislou sobre o que o costume tinha criado: o laudo arbitral teria um valor intrínseco (não mais seria exequível bona fide ou mediante a execução da penalidade, se esta houvesse) e nas condições de terem as partes jurado conformar-se com a decisão arbitral e na de ter o árbitro igualmente jurado cumprir com seu encargo. Instituíase, ao mesmo tempo, uma ação real perante o magistrado, conditio ex lege ou actio in factum para compelir a parte recalcitrante à execução do laudo arbitral, estando vedado ao juiz julgar o fundo ${ }^{14}$. Posteriormente, na sua primeira Constituição, Justiniano modificaria o sistema, devido a freqüentes perjúrios das partes interessadas em iludir o laudo arbitral;

11. Coulanges, id., p. 379.

12. MaRgarite LANDRAU, L'Arbitrage dans le Droit Anglais et Français Comparés, Paris, Lib. Arthur Rrousseau, 1932 (tradução livre), p. 11.

13. apud LANDRAU, id., p. 11.

14. Com razão, LANDRAU aponta o paralelismo de tal procedimento com os modernos princípios do exequatur de sentenças estrangeiras; acrescente-se, igualmente, o paralelismo da aprovaçăo dos laudos arbitrais pela justiça togada e, ainđa, a homologação dos laudos arbitrais estrangeiros pela justiça togada, nos sistemas que o permitem (Inglaterra). 
determinaria que o magistrado interviria na execução do laudo, se tivesse havido uma anterior stipulatio poenae, no compromisso ou na cláusula compromissória.

Note-se, assim, que, se, no terreno das relações com outros povos, a contrário das relações no mundo pan-helênico, o direito romano regrediu na aplicação da arbitragem, nas relações entre particulares, tornaram o instituto mais consentâneo com o mundo dos negócios. Outro fator importante a observar na evolução da arbitragem é que, sob a influência do ideário cristão, a arbitragem se estenderia para um domínio cinza, entre público e privado, para incluir casos em que ela se torna forçada, ao se estabelecer, necessariamente, os bispos, como árbitros nas causas entre religiosos e leigos.

Durante a Idade Média, ao prevalecer a pax christiana, "a arbitragem pelo Imperador ou pelo Papa era o julgamento do superior (temporal ou espiritual) ${ }^{15}$. Acrescente-se que tal ocorria, não unicamente com as arbitragens de caráter público, mas igualmente com as outras formas de soluções pacíficas de controvérsias, pois várias são as interferências dos nuntii ou internuntti, enviados do Papa, seja como mediadores, conciliadores em assuntos políticos das comunas e das ordens religiosas, organizações essas que, por vezes, tinham na prática um poder verdadeiramente político. Outra circunstância a observar é que, em várias partes da Europa medieval, decretos locais atribuiam aos bispos o conhecimento de causas que versassem sobre conflitos entre parentes em matéria de partilha ou de tutela, alargando o âmbito do decreto justinianeu que lhes atribuía competência arbitral obrigatória em questôes entre clérigos e leigos.

Três razões, segundo TAUBE, explicariam o enorme sucesso da arbitragem na Idade Média. Em primeiro lugar, havia reiterada prática arbitral no seio da Igreja Católica Romana,

15. Charles Rousseau, Droit International Public, Paris, 6.8 ed. Dalloz, 1971 , p. 300 (tradução livre). 
na sua jurisdição eclesiástica, que era bastante extensa, dado ao fato de que os clérigos eram proprietários de grandes áreas de terra; explica-se a origem de tal prática arbitral pelo fato de ser mais fácil a uma comunidade resolver os litígios entre seus membros por maneiras não judiciais, especialmente em face das proibições de São Paulo aos coríntios de recorrerem à justiça romana (I Cor., VI, 1 e seguintes) Em segundo lugar, houve o surgimento de arbitragens intermunicipais, à semelhança da existente na Grécia antiga, para resolução de litígios territoriais, em contraposição à justiça oferecida pelo Sacro Império Romano Germânico, que pesava profundamente sobre as comunas; natural, pois, que à medida em que se descobria o direito romano, se aplicassem as soluções pragmáticas de direito privado àquelas questões que hoje seriam de direito público. Em terceiro lugar, o sistema feudal, com a atomização do poder, concentraria na figura dos proprietários de terras, hierarquicamente superpostos e ligados entre eles mesmos e ao rei, um sistema de direitos recíprocos, onde não haveria distinção entre público e privado; o recurso à arbitragem pelo superior hierárquico, para resolver questões privadas, seria igualmente uma solução para assuntos hoje de pertinência do direito internacional público.

A partir do século XII, a Idade Média está repleta de casos de arbitragem, entre cavaleiros, entre barões, entre proprietários feudais, e entre soberanos distintos. A guisa de exemplos citem-se, em 1264, São Luiz, rei de França, exerceu o papel de árbitro entre Henrique III da Inglaterra e seus barōes e, em 1268, entre os condes de Luxemburgo e do Bar; em 1244, o parlamento de Paris arbitrou questões entre o Papa Inocêncio IV e o imperador Frederico II. A linha de Tordesilhas fixada pela bula do Papa Alexandre VI, nada mais foi do que uma decisão arbitral, em que se dividiriam entre Espanha e Portugal os eventuais descobrimentos no Novo Mundo. Enfim, acentue-se o fato de que, especialmente nas corporações de ofícios e de profissões liberais, onde imperava rígida hierarquia entre os membros, era natural que se bus- 
cassem soluções de controvérsias, por meio de recursos que não saíssem do âmbito daquelas comunidades.

Foi na Idade Média que surgiu um novo tipo de arbitragem, a arbitragem comercial: "os comerciantes preferiam aos julgamentos dos tribunais, as decisões de árbitros escolhidos por eles, mais rápidos e mais competentes em matéria cơmercial ${ }^{16}$ Nas feiras, onde se reuniam comerciantes de várias nacionalidades, funcionavam tribunais arbitrais, que, na verdade, eram mais expeditos que os tribunais judiciários locais, que deveriam, caso a eles se recorresse, aplicar leis estranhas ao foro, num sistema onde imperava a extrema personificação da lei e a mais ampla extraterritorialidade dos estatutos pessoais; a arbitragem permite o recurso à eqüidade e à aplicação de usos e costumes vigentes para as partes, constituindose, por tais razões, um meio de solução pacífica de litígios, mais consentâneo com o mundo dos negócios. Um decreto de São Luiz de 1250, mandava que se fizesse uma lista de comerciantes engajados em várias atividades mercantis, a fim de que pudessem ser compostos os tribunais arbitrais. LANDRAU acrescenta em abono do fato de haver a arbitragem entrado tão bem nos costumes mercantis, que uma lei de 1637, em França, mandava considerar-se de ofício, no caso de inexistência, nos contratos de sociedade ou de seguro marítimo, cláusulas compromissórias para determinadas matérias e, indicação pelo tribunal judiciário, no caso de revelia ou não cooperação, do árbitro não indicado pela parte.

Interessante observar que, na Idade Média, a partir da terminologia legal, haveria a possibilidade de mediação nos negócios entre particulares. Boutillier, jurista francês do século XIV, repete os conceitos das mais antigas legislações: "árbitro não pode e não deve, na causa a ele submetida, proceder senão por ordem do direito vigente, segundo o alegado - ou provado perante ele - mas fazer tudo segundo a regra

16. LANDRAU, id., p. 13. 
de direito; arbitrador, se é aquele que da causa é encarregado pela sua consciência, segundo o direito ou não; mediador ou apaziguador, se é aquele que, com o consentimento das partes, as coloca em acordo ${ }^{17}$. TAube conclui que, na Idade Média, as figuras do mediador e do arbitrador estariam reunidas numa só pessoa, fato que discordamos. No nosso entender, apesar das definições dos dicionários ${ }^{\mathbf{1 8}}$, conceituamos árbitro como aquele que julga uma causa, segundo a lei da sede do tribunal ou segundo a eqüidade, (se as partes assim dispuseram e se aquela lei o permitir), num processo instituído pelas partes, segundo um ritual definitivamente caracterizado; arbitrador, aquele que exerce a peritagem técnica, a pedido de uma das partes, de ambas ou de um terceiro na relação contratual (o juiz, por exemplo), sem necessidade de ritos definitivos; mediador, ou apaziguador, ou ainda amigável compositor,

17. apud TAUBE, id., p. 88/89: "arbitre ne peut et ne doit en la cause à luy submise procéder autrement qua par ordre gardé selon qu'il est allegué -- ou prouvé devant luy - mais tout laisser selon la reigle de droit. Arbitrateur si est celuy qui de la cause est chargé à sá conscience, ordre de droit gardé ou non gardé. Amiable compositeur si est celuy qui du consentement des parties les met en accord"

18. O Novo Dicionário Aurélio distingue arbitrador (que ou aquele que arbitra; arbitrar, Julgar como árbitro; fixar quantia por arbitrio; decidir, resolver segundo a própria consciência; atribuir judicialmente, adjudicar) de árbitro' (aquele que dirime questóes por acordo das partes litigantes ou designação oficial, mediador; aquele que é chamado para, como juíz, dirimir dúvidas, opinar em debates, julgar algum assunto, decidir sobre alguma colsa; aquele que dirige um jogo ou prova esportiva, com direito de decisão quanto ao seu desenvolvimento ou aos fatos disciplinares; senhor absoluto, soberano; modelo, regra, exemplo: é um árbitro da elegância). Igualmente o mesmo dicionário coloca como perfeitos sinônimos os conceitos de arbitração, arbitragem e arbitramento. Contudo, a lei (Código Civil, art. 1.037, CPC, art. 1.072 e seguintes), a doutrina e a própria jurisprudência arbitral internacional apelam árbitros, aqueles que desempenham o julgamento arbitral; arbitrador, reserva-se para os que desempenham peritagem técnica. De igual forma, textos constitucionais bra-

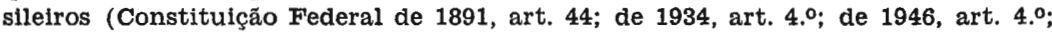
de 1967 , art. $7 .^{\circ}$ e Emenda de 1969 , art. $7 .^{\circ}$ nas primeiras, arbitramento, nas duas últimas, arbitragem), a praxe internacional e os precedentes orbitrais têm reservado para arbitragem (sinônimo, arbitramento) as atividades de julgamento arbitral "stricto sensu" e arbitração, peritagem técnica ou determinação de meros fatos realizada por terceiros, sem a necessidade do rito processualístico do verdadeiro jufzo arbitral. A confusão terminológica é 1gualmente presente no direito anglo-norte-americano; apesar dos dicionários jurídicos, a praxe mostra que arbiter é o juiz arbitral, arbitration, a peritagem técnica e a arbitragem; arbitrator e arbitrage, palavras em relativo declínlo. 
aquele que decide, por permissivo das partes, mas cuja decisão não é obrigatória para as partes, nem se acha restrito a decidir segundo algum rito. Feitas as distinções, cremos que na Idade Média, teria havido, distintamente, as três figuras citadas por Boutillier.

Foi, igualmente, o comércio entre as cidades do norte da Itália o responsável pelo aparecimento do predecessor do moderno diplomata, que seria nos séculos seguintes, o grande fautor das soluçôes pacíficas de litígios entre Estados, inaugurando a forma da negociação diplomática. Mantidas tais cidades fora do principal sistema medieval, eram elas "interconectadas por incontáveis interesses comuns, assim como rodeadas de ferozes rivalidades ${ }^{19}$. Excelentes mercadores, os italianos sentiram a necessidade de formar pessoal treinado para bem negociar com estrangeiros ou serem enviados a lugares estrangeiros para aí realizarem o comércio; deveriam tais prepostos estar capacitados a transportar, com segurança, grandes quantidades de valores, pelos despoliciados caminhos medievais. Aos poucos, em Florença, formou-se um corpo de especialistas que, na época, não estavam a serviço de um único governante, mas que podiam ser contratados por quem desejasse negociar com estrangeiros ou noutras cidades ${ }^{20}$. Paralelamente, criavam-se grupos armados permanentes, com salários pagos pelos interessados, e que deveriam acompanhar e proteger aqueles prepostos. Estavam, assim, lançados os alicerces do Estado moderno, com os primórdios da diplomacia institucional, posteriormente vinculada a um único governante, o monarca, e, modernamente, ao Estado, bem como a instituição dos exércitos permanentes, que com a diplomacia,

19. HAROLd Nicholson Diplomacy, 3.a edição, Oxford University Press, Londres, 1969, p. 12 (tradução livre).

20. O fato de, modernamente, os Estados poderem representar interesses de outros em terceiros paises (no caso de rompimento de relaçóes diplomáticas), revela a origem negocial da diplomacia. Um caso famoso de diplomata representar país que năo é de sua nacionalidade, fol $\circ$ do fundador do D. I. Público, Hugo Grotius, holandês, Embaixador da Suécia em Paris. 
constitue-se nos fundamentos da política exterior dos Estados modernos.

Unificados na pessoa dos Reis católicos, os primeiros Estados na moderna acepção, Espanha e Portugal, partem para a conquista do Novo Mundo. Problemas novos são criados, à vista dos estranhos seres que habitavam as Américas; ingênuos, politeístas, vivendo alguns na infância da civilização, outros, numa civilização incompreensível para os europeus, perguntavam-se estes se aqueles seriam mesmo seres humanos, e o relacionamento com eles deveria ser de santa hostilidade, como o fora com os infiéis, os muçulmanos, e quais os títulos jurídicos que dariam apoio às conquistas de territórios. Colocava-se, na verdade, a questão mesma que fundamenta o $\mathrm{Di}$ reito Internacional Público, qual seja, a regulamentação das relaçōes entre agrupamentos humanos diferenciados por valores, mas unificados por alguns outros, que possibilitam aquele relacionamento mesmo. Tratava-se, pois, de descobrir o horizonte comum a todos os homens, onde pudessem fincar as bases de um sistema normativo entre unidades políticas diferenciadas ${ }^{21}$.

Ainda à Igreja Católica, responsável pelo aperfeiçoamento da cultura e da civilização na Idade Média, guardiã da cultura greco-romana clássica, celeiro dos melhores pensadores de todos os tempos, à cuja sombra surgiria a universidade, caberia propiciar a descoberta dos valores comuns a todos os homens e lançar os fundamentos do moderno Direito Internacional Público, e todo o seu repertório de soluções pacíficas de controvérsias. Elaborando os conceitos de direito natural, já presentes na melhor tradição greco-romana, revalorizados no Novo Testamento e tornados sistematizados pelos pensadores medievais, os teólogos espanhóis do tempo do Siglo d'Oro, com destaque do dominicano Francisco DE VICTORIA

21. A rigor, só se pode falar na existência de Estados, no momento do nascimento deles (Paz de Vestfália de 1648). 
(1480-1546), deram nova direção ao que GaIo chamava jus gentium e definia como quod naturalis ratio inter omnes homines constituit (Gai., 1,1) e que VICTORIA, mantendo a definição, denominaria de jus inter gentes; a direção referida foi no sentido de, novamente, trazer para a esfera do conceito de direito jurídico natural, que se encontrava, então, nos domínios da Teologia e da Ética. Na concepção de Francisco VICTORLA, haveria um direito natural imanente e objetivo, que diria da validade de quaisquer outros direitos, pois, tendo sido colocado por Deus, não poderia ser revogado pela autoridade dos homens, inclusive um rei, como Henrique IV, que assistia às suas preleções em Salamanca. Em época posterior, outro precursor do Direito Internacional Público, o jesuíta espanhol Francisco Suares (1548-1617), introduziria uma distinção no conceito: ao lado do direito natural imanente às sociedades dos homens, criado por Deus, há outros que se podem descobrir nas várias legislações dos povos e que são comuns a todas: estes são obra dos homens, que os criam por prática generalizada. Tal elemento voluntarista permitiria a elaboração do conceito, até o ponto em que o holandês Hugo Grocio (1583-1642), considerado o fundador do Direito Internacional o expôs; reconhecendo com os teólogos espanhóis a distinção entre direito natural e direito internacional positivo, à diferença de Suarez, Grocio fá-lo brotar não do costume, mas de acordos entre Estados (jus gentium voluntarium). Indo mais além, Grocio não se limita a reconhecer o direito natural como fundamento do Direito das Gentes, mas elabora um verdadeiro sistema de direito das gentes, completo e modificável por normas positivas. Seu tratado "De Jure Belli ac Pacis" iria decisivamente influenciar todos os escritores que se seguiriam.

Hugo Grocio bem representa o espírito de seu tempo. Tendo sido embaixador da Suécia em Paris, tendo participado das longas negociações que conduziriam à assinatura dos Tratados de Vestfália de 1948, que finalizaram com a Guerra 
dos Trinta Anos, pôde detectar a existência de um direito entre as unidades políticas que então se formavam, os Estados, formular suas bases, estabelecer seus princípios e indicar os caminhos ideais pelos quais deveria prosseguir, no sentido de evitar confrontações bélicas entre os sujeitos cuja ação regulava. Já nos mencionados Tratados de Vestfália, há a marca indelével do estabelecimento definitivo dos Estados modernos; colocando fim a uma das muitas guerras de religião, os tratados firmaram a vinculação definitiva da ordem e da lei ao território da autoridade governante, sem quaisquer intermediários ou superiores: hujus regio, ejus religio, onde hujus e ejus se referem aos nobres que tinham tomado parte na mencionada guerra. Assinados em Münter (católicos) e Osnabrück (protestantes), colocam os Tratados de Vestfália um fim à pax christiana e a qualquer veleidade de o Papa ou o Imperador servirem de árbitros perpétuos nas disputas políticas, já que a Guerra dos Trinta Anos tinha sido a suprema tentativa da Igreja Católica e da Casa dos Habsburg de unificar a Europa pela extirpação do protestantismo e pelo triunfo de uma monarquia católica universal. Com base territorial fortẹmente assentada, com o poder concentrado numa pessoa e não mais atomizado entre burgos, corporações, ordens de pertença por nascimento a diversos estamentos, com sua autoridade máxima laicizada, no Estado moderno, as relações internacionais tendem a encontrar soluções pacíficas de litígios em novas formas, de fundo eminentemente concensual, onde o público e o privado se encontram em rígida separação.

E evidente que, com tal conformação política, no Estado moderno de forte base territorial, as leis perdessem seu caráter de normas comuns às unidades políticas e, cada vez mais, ganhassem peculiaridades nacionais. Reaparece a antiga distinção de Ulpiano entre direito público (quod ad statum rei Romanae spectat) e direito privado (quod ad singulorum utilitatem spectat) e, ainda, se cria outra, até o momento inexistente: direito interno e direito das gentes, ou internacio- 
nal $^{22}$ As arbitragens entre Estados se retraem e, os estadistas, como que esquecidos da tradição e dos precedentes existentes na Idade Média, irão elaborar um desenvolvimento diferente, a partir do aparecimento de comissões mistas e a eleição de um estranho à lide, como desempatador.

Em semelhante clima propício à diversidade legislativa, e na medida em que as transações entre homens não conhecem fronteiras, apesar de os poderes judicantes estatais se encaminharem para um enrijecido nacionalismo, as soluções extrajudiciais para litígios entre particulares continuam a ter suas aplicações. A existência de tribunais privilegiados para os nobres, a lentidão e os custos elevados dos processos, fazem a popularidade da arbitragem e causam as tiradas sardônicas contra a justiça togada, como na Fábula L'Huître et les Plaideurs de La Fontaine ${ }^{23}$.

No que respeita à solução pacífica de litígios entre Estados, a doutrina ganha novas valorações, com as obras que buscam estabelecer as condições de uma paz perpétua. Alguns autores aventam uma idéia de organização federativa entre os Estados: Eméric Crucé (O Novo Cynée ou Discurso sosobre as ocasiões e meios de estabelecer uma paz geral e a liberdade do comércio em todo o mundo - 1623), Sully (O Grande Desígnio - 1611/38), William PenN (Projeto para uma paz presente e futura - 1693), do AbBé de SAINT-Pierre (Memória para tornar a paz perpétua na Europa, de 1712 e Projeto para a paz perpétua na Europa - 1713/16) e JEREmias Bentham (Projeto de paz universal e permanente 1789). Outros, como Emanuel Kant, dando-se conta da irrealizabilidade de uma sociedade de nações ou de formas federativas entre Estados, prognostica ser um imperativo da razão a que os Estados se acerquem da realidade deste Foedus

22. O termo internacional só seria criado, no Século XVIII, por Jeremias Bentham.

23. Mettez ce qu'il en coûte à plaider aujourd'hui. Comptez ce qu'il en reste à beaucoup de familles: Vous verrez que Perrin tire l'argent à lui. Et ne laisse aux plaideurs que le sac et les quilles. 
Amphictyonum, através de uma cooperação permanente e decidida entre si (Sobre a Paz Perpétual - 1795).

Se por um lado "a doutrina antigo-medieval do bellum justum se esvai pouco a pouco, substituindo-a a concepção de que todo o Estado tem o direito de declarar a guerra, se assim o exigem seus interesses" ${ }^{24}$, por outro, a intensa movimentação diplomática aperfeiçoaria os mecanismos da negociação e dos bons ofícios. $\mathrm{O}$ intrincado sistema de alianças e de ligações entre as famílias reinantes, favoreceria um sistema de soluções pacíficas de controvérsias entre os membros do sistema e, definitivamente, introduziria as noções de consulta prévia aos aliados, em casos que envolvessem a ação estratégico-diplomática do Estado, na época, confundido com a pessoa do monarca.

A Revolução Francesa representa o maior interesse para o estudo das soluções pacíficas de controvérsia. Os Decretos de 16 e 24 de agosto de 1791 qualificam a arbitragem entre particulares como "o meio mais razoável de terminar uma contestação entre cidadãos" e, acrescentam, "os legisladores não poderão baixar nenhuma disposição que tenda a diminuir, seja o favor, seja a eficácia do compromisso" A Constituição de 3 de setembro de 1791, expressamente dispunha que "o direito dos cidadãos de terminar definitivamente suas contestações pela via da arbitragem, não pode sofrer qualquer lesão pelos atos do poder legislativo" (Tit. III, Cap. V, art. 5.9) O prestígio da arbitragem aumenta, com as leis do período da Convenção tendo multiplicado os casos em que se tornam obrigatórias as arbitragens entre particulares.

Não pode ser esquecida a importância de ter a Revolução Francesa consagrado a filosofia do Iluminismo, na Declaração dos Direitos do Homem e do Cidadão, de 26 de agosto de 1789, posteriormente colocada no umbral da Constituição

24. AlFred Verdross, Derecho Internacional Público, Madrid, 5.a ed., 1967, p. 37 (Em tradução da edição em espanhol, livremente, pelo autor). 
de 1791. Em especial, note-se que, no seu art. $6^{\circ}$ (Todos os cidadãos sendo iguais aos olhos da lei, são admissíveis a todas as dignidades, lugares e empregos públicos, segundo sua capacidade, e sem outra distinção que a de suas virtudes e de seus talentos), abriam-se as portas para a democratização da carreira diplomática. De um modo geral, ao permitir o controle democrático dos atos do Executivo, dos quais se cita o das relações exteriores do Estado, a Revolução. Francesa deu ao cidadão o controle dos negócios internacionais e, conseqüentemente, responsabilizou-o pela paz e pela busca de soluções pacíficas de litígios com outras Nações.

Ainda no espírito revolucionário, mas já no Império, a grande contribuição de França para o tema, foi a publicação de 21 de março de 1804 (ou seja, de 30 Ventoso, ano XII), do Código Civil dos Franceses (Código Napoleão), obra monumental de codificação dos direitos privados, que o gênio de Napoleão considerava sua obra mais importante. Tendo sido o modelo para um sem número de outras codificações que se seguiriam, foi o responsável pela disseminação de princípios de direito privado uniformes.

As arbitragens entre Estados desconhecem os precedentes dos julgamentos arbitrais feitos por um superior hierárquico, como na Idade Média, e repartem de uma prática diplomática que se aperfeiçoou, as comissões mistas. De início, simples procedimento bilateral, tais comissões mistas evoluíram no sentido de instituírem um terceiro, não parte no litígio, que pudesse eventualmente realizar o desempate. Tal procedimento se desenvolve a partir do Tratado Jay de 1794, entre a Inglaterra e o país recentemente independente, os Estados Unidos da América, generalizando a prática da instituição do superárbitro, elemento neutro e eleito pelos árbitros (em inglês, umpire) Charles Rousseau ${ }^{25}$ mostra o inconveniente de tal forma de arbitragens entre Estados, pois careciam de uma autoridade, a menos que fossem prolatadas

25. op. cit., p. 302. 
por um Chefe de Estado as sentenças arbitrais, e aponta o posterior desenvolvimento histórico, no sentido de encontrarem-se unidas as duas formas, nos séculos posteriores, de arbitragem por comissões mistas, onde o superárbitro é um chefe de Estado.

Desarticulado o sistema internacional da Paz de Vestfália, ruído ficou o "Ancien Regime" Exilado Napoleão, reuniu-se o Congresso de Viena em 1815 para restabelecer-se a paz na Europa e reorganizar as relações internacionais. O sistema que se segue, Concerto Europeu, caracterizou-se pela responsabilização da paz aos Grandes de então, França, Inglaterra, Prússia, Rússia e Império Austro-Húngaro, que se comprometiam a consultar-se, reciprocamente, no caso de tomada de decisões que pudessem afetar o equilíbrio na Europa. Seguiu-se uma política de intervenção das Grandes Potências nos países periféricos, mas, de qualquer forma, houve certo equilíbrio de forças, embora nem sempre a referida consulta fosse realizada; tal equilíbrio, em parte, deveu-se ao fato de que o sistema de alianças era extremamente flexível, dada uma conformação de Estados com relativo poder semelhante, os alinhamentos diplomáticos permitiam um não enrijecimento de blocos antagônicos. Como a Inglaterra servisse de fiel da balança em manter o equilíbrio, inclinando-se para as formações diplomáticas que melhor compensassem um crescimento de outras formações, o período tem sido conhecido como o da pax britannica.

A diplomacia, definitivamente, passou a caracterizar-se como serviço público do Estado, e não mais como um serviço pessoal prestado ao governante, e, fato importante, teve suas funções regulamentadas no Congresso de Viena de 1815, mais tarde complementadas pelo Protocolo de Aix-la-Chapelle de 21 de novembro de 1818. Documentos implortantes formalizavam os costumes internacionais, tornando mais intensa a movimentação diplomática, já favorecida com os sistemas de alianças, propiciando o aperfeiçoamento das técnicas de soluções pacíficas de controvérsias, em especial, da negociação. 
A partir de 1872, casos que poderiam ter causado a guerra, são resolvidos por arbitragens entre Estados. Três são célebres: o caso Alabama, navio sulista armado na Inglaterra, com a abstenção complacente desta, e que causara sérios danos aos navios mercantes que mostrassem simpatia pela causa dos nortistas, no curso da Guerra da Sucessão nos EUA (arbitragem em 1872, que reconheceu as reclamações dos EUA contra a violação da neutralidade por parte da Inglaterra, e foi resolvida por um tribunal arbitral reunido em Genebra, com os árbitros indicados pelo Presidente dos EUA, a rainha da Inglaterra, o rei da Itália, o Presidente da Confederação Suíça e o Imperador do Brasil, que nomeou o Visconde de Itajubá, na época, enviado extraordinário e ministro plenipotenciário do Império brasileiro em Paris); o litígio entre os mesmos países, a propósito de focas de pele no mar de Bhering (1893) e o litígio sobre fronteiras nos Andes entre a Argentina e o Chile (1902) Na época, o Brasil funcionou como árbitro, ainda, em casos de reclamações mútuas franco-americanas (1884), reclamações da França, Itália, Grã-Bretanha, Alemanha etc., contra o Chile (1882/1887)

O Brasil recorreria à arbitragem internacional em vários casos. Na Questão Christie (agressão de três oficiais inglêses, à paisana à sentinela do posto oficial da Tijuca, e indenização pecuniária pelo naufrágio da barca inglêsa Prince of Wales no Rio Grande do Sul), resolvida por arbitragem do Rei Leopoldo da Bélgica, daria ganho de causa ao Brasil (1863) As questões entre o Brasil e os EUA, relativas ao naufrágio da galera norte-americana Canadá, no Rio Grande do Norte, resolvido pelo enviado extraordinário e ministro plenipotenciário da Grã-Bretanha em Washington, condenou em 1870 o Brasil a pagamento de indenização. A Reclamação do cônsul-geral da Suécia-Noruega, pelo abalroamento da barca norueguesa Queen, pelo monitor brasileiro Pará, em Assunção, foi resolvida pela arbitragem do enviado extraordinário e ministro plenipotenciário de Portugal no Rio de Janeiro. Foi, contudo, nas questões de limites que o Brasil 
mais se destacou com o recurso às soluções arbitrais. A Questão do território de Palmas (limites entre o Brasil e a Argentina), resolvida pelo Presidente dos EUA, Cleveland, em 7 de setembro de 1889, foi favorável à tese defendida pelo advogado do Brasil, o Barão do Rio Branco. A Questão do Amapá (fronteiras entre o Brasil e a Guiana francesa) foi resolvida pela arbitragem do Conselho federal da Suíça, tendo o laudo sido proferido pelo Presidente da Confederação Suíça, em $1 .^{\circ}$ de dezembro de 1900, a favor do Brasil; o ad'vogado brasileiro foi, igualmente, o Barão do Rio Branco. Na Questão de Limites entre o Brasil e a Guiana Britânica, (Questão do Pirara), funcionou como árbitro o Rei Victorio Emmanuelle III da Itália; decidiu contra as argumentações de Joaquim Nabuco, advogado do Brasil, em laudo de 6 de junho de 1904, que recebeu críticas dos internacionalistas da época ${ }^{26}$.

A partir das tentativas feitas na Primeira Conferência de Paz da Haia, criava-se em 1899, com sede naquela cidade, uma Corte Permanente de Arbitragem, até hoje existente; constava de uma lista de árbitros a serem escolhidos no caso de litígios entre Estados, bem como de um Secretário permanente com assento na sede do tribunal. No seu final, assinaram-se três convenções, uma das quais, sobre soluções pacíficas de controvérsias, que foi votada por unanimidade dos 26 Estados participantes. A Segunda Conferência de Paz da Haia, que agrupou 44 Estados, com a participação de Estados não europeus, igualmente, aprovaria 13 convenções, uma declaração afirmando o princípio do recurso à arbitragem, obrigatório; uma das convenções consagra a idéia do jurista russo VON MARTENS, da instituição de comissões internacionais de investigação, como formas novas de soluções pacíficas de controvérsias. Note-se que a convenção da Haia de 1907 representa um dobrado interesse nos dias atuais, uma vez que sua jurisdição pode ser estendida, conforme o precedente arbitral

26. Veja-se, sobretudo, em Hildebrando Accioly, Tratado de D. I. Público, 2. ${ }^{\text {a }}$ ed., vol. III, 1957, p. 59 e segs. 
de 1934, em Radio Corporation of America versus Governo chinês, a questões que envolvam um Estado e uma pessoa de direito privado, representando, assim, uma das várias possibilidades de formar-se jurisdição em questões que dizem respeito à atuação das multinacionais (casos de arbitragem semiinternacionais).

Quanto às arbitragens entre particulares, na maioria dos países de direito codificado ("civil law"), sofreram restrições com a promulgação dos Códigos de Processo Civil. Na França, por exemplo, com reação à liberalidade do período revolucionário, restringiram-se os casos de serem objeto de compromisso (arbitrabilidade), extinguiu-se a arbitragem obrigatória e cerceou-se $o$ ato de condições de validade bastante severas: o laudo arbitral é sempre suscetível de revisão pelo judiciário e perde o caráter de auto-exequível, se não for homologado pela justiça togada. No sistema de direito jurisprudencial ("common law") a tendência é deixar a arbitragem praticamente regulamentada entre as partes, com mínimas exigências nos estatutos e na regra do precedente judicial (na Inglaterra, por exemplo, o laudo arbitral é auto-exequível, dispensando homologação judicial para sua execução; nos EUA, concede-se "specific performance" para a parte que não cumpriu a cláusula compromissória ou o compromisso e que recorreu aos tribunais).

Ainda na técnica das soluções pacíficas de controvérsias, no período anterior à Primeira Guerra Mundial, viram-se aparecer os delineamentos dos primeiros organismos internacionais, as uniões administrativas, já indicativos do espírito federalizante característico do século XX. Em 1878 criava-se a União Postal Universal; a seguir, várias uniões se estabeleceram: União Radiotelegráfica Universal, e em múltiplos domínios, para o sistema métrico (1875), para a proteção da propriedade industrial (1883) literária e artística (1884), para as estradas de ferro na Europa (1890) Deve notar-se que tais uniões administrativas eram mais órgãos técnicos de troca de informações entre os Estados do que, realmente, organismos 
internacionais onde se exerce uma diplomacia parlamentar em busca de soluções pacíficas de litígios, tipicidade reservada à época das relações internacionais após 1919.

A Primeira Guerra Mundial viria dar um golpe de morte no sistema do Concerto Europeu, que principiara a mostrar sinais agônicos desde a guerra franco-prussiana e da unificação da Alemanha e da Itália, que se constituíram novos focos de poder, colocando o equilíbrio na Europa em profundo abalo. Guerra total, envolvendo populações e indústrias civis, com objetivos globais, fortemente apoiada no reforço da retaguarda civil, levaria a destruição para além das linhas de combate e exigiria a participação forçada de todos os cidadãos, soldados ou civis, indiscriminadamente. De tal forma globalizada, exigiria, por outro lado, uma paz com objetivos igualmente globais, que atendessem aos reclamos de cumprimento das promessas feitas na época da mobilização nacional, de melhoria do nível de vida e de melhor situação do operário, que tinha sido, com seu trabalho redobrado, igualmente, o fator da vitória. Por tais razões, os Tratados de Versalhes de 1919 marcam o nascimento do Welfare State, que se caracterizaria por uma crescente intervenção do Estado em assuntos que, na forma anterior do Etat Gendarme, eram deixados ao livre jogo das forças sociais, governados, em plena liberdade, pela "hidden hand" smithiana.

Pela primeira vez na História, o Novo Continente participaria de uma guerra européia, de natureza total, e também, pela primeira vez, o ideário de um Presidente americano tentaria colocar-se na diplomacia mundial. Nos famosos $\mathrm{Ca}$ torze Pontos, o Presidente W Wilson dos EUA transporia valores norte-americanos para a política internacional, como exigência da participação daquele país na Grande Guerra: no I Ponto, uma diplomacia pública de tratados e negociações abertas (open covenants of peace, openly arrived at) e, no XIV Ponto, a instituição de um sistema de relações internacionais, baseado na responsabilidade ilimitada e coletiva de 
todos os Estados, com a criação de um organismo internacional que julgasse as ameaças à paz, pela unanimidade de seus membros.

Os Tratados de Versalhes de 1919 buscaram, na verdade, instituir o. Welfare State com a criação da Organização Internacional do Trabalho (OIT), a primeira organização internacional, no sentido atual, com estrutura e personalidade jurídica internacional. A diplomacia aberta era instituída, mediante a obrigatoriedade de registro de tratados internacionais na Secretaria da Sociedade das Nações, organismo internacional criado na ocasião, e que se incumbiria de publicá-los (art. 18 do Pacto) Quanto à organização da paz, à Liga das Nações (ou Sociedade das Nações) caberia o papel de assegurar um mecanismo de consultas diplomáticas em nível permanente e institucional, garantindo as decisões do organismo internacional, que deveriam ser tomadas por unanimidade de seus membros.

Importante foi a contribuição do sistema instalado em 1919 para as soluções pacíficas de controvérsias. No campo da diplomacia, inaugurou-se um novo tipo de contacto diplomático, a diplomacia parlamentar, espécie do gênero diplomacia multilateral, que se torna institucionalizada e permanente no seio das organizações internacionais, bem como aperfeiçoou outro, a diplomacia de cúpula, que consiste no contato dos Chefes de Estado ou de seus Ministros das Relações Exteriores, diretamente com seus pares. A melhoria dos meios de comunicação e de transporte facilitam a negociação, tornando-a mais flexível. Criam-se funcionários internacionais, que deveriam ocupar cargos no Conselho, Assembléia e Secretariado da Liga das Nações. Aparece mais uma figura de apaziguador, conciliador e mediador na cena internacional, o Secretário da Liga.

A arbitragem entre Estados é regulamentada pelo Ato Geral de Arbitragem, assinado em Genebra em 1928, que "constitui um verdadeiro código de procedimentos interna- 
cionais concernente, malgrado seu nome, não só à arbitragem, mas ainda à conciliação e o recurso judicial ${ }^{27}$, adotado por ocasião da Nova Assembléia Geral d’a Sociedade das Nações. Nas suas mais importantes disposições do Ato Geral previa, no caso de litígios entre Estados, o recurso a uma comissão mista de conciliação; no caso de fracasso da mesma, os litígios de natureza política, e que versassem sobre assuntos de "lege ferenda", seriam resolvidos por arbitragem, admitindose a solução "ex aequo et bono", e os litígios de natureza jurídica, com base na interpretação de um direito existente entre as partes, seriam resolvidos, judicialmente, pela Corte Permanente de Justiça Internacional.

Por mandamento do artigo 14 do Pacto, criou-se um tribunal internacional de âmbito mundial, o primeiro na História do Homem, cujos estatutos foram adotados pela Assembléia da Liga em 1920, e ao qual a maioria dos Estados integrou $^{28}$. Era, assim, inaugurada a forma mais perfeita de solução pacífica de controvérsias entre Estados: a maneira judicial. Contudo, nem todos os Estados reconheceriam, per se, a jurisdição da Corte. Imaginou-se uma cláusula, posteriormente integrada nos Estatutos, cláusula facultativa de jurisdição obrigatória, pela qual, aos Estados se facultava adotar a jurisdição automática da Corte. Assim sendo, no sistema da Corte, e que persiste até nossos dias, há duas situações: a) jurisdição automática da Corte, quando ambas as partes num litígio reconhecem a competência obrigatória da mesma; b) jurisdição instituída por compromisso, que reconhece e delimita a jurisdição da Corte, possível entre os Estados signatários da referida cláusula de um lado, e do outro, Estados não signatários. A obra da Corte, e sua sucessora, a Corte Internacional de Justiça, esta já no sistema da ONU, tem contri-

27. Claude-Alberto Colliard, Institutiones des Relations Internationales, 6. ${ }^{a}$ ed. Paris, Dalloz, 1974, p. 53 (traduçāo livre do autor).

28. Na verdade, a primeira corte internacional foi a Corte de Justiça Centroamericana, que existiu de 1907 a 1917, entre Costa Rica, Guatemala, Honduras, Nicarágua e Salvador. 
buído para enriquecer a jurisprudência internacional, em obra da maior autoridade científica.

Quanto à arbitragem entre particulares, firmam-se dois importantes diplomas internacionais: a) a Convenção de Genebra de 26-9-1927, sobre execução de sentenças arbitrais estrangeiras e b) o Protocolo de Genebra de 24-9-1923, relativo à cláusula arbitral, este ratificado e decretado como lei interna no Brasil (Decreto 21.187 de 22 de março de 1932) Assim sendo, e em que pesem opiniões em contrário de que o Código de Processo Civil de 1939 teria revogado o mencionado Protocolo de Genebra de 1923, seguimos o princípio universalmente aceito e confirmado pelo Supremo Tribunal Federal ${ }^{29}$ de que uma convenção. internacional só se revoga com a denúncia, que no caso nunca houve, e, portanto, reconhecemos ser lei vigente no Brasil e para as relações comerciais em que apareça um elemento conectado com a lei brasileira, os princípios do Protocolo de Genebra de 24-9-1923 ${ }^{30}$. São eles: a) o reconhecimento de compromissos ou cláusulas compromissórias em contratos comerciais celebrados entre partes submetidas à jurisdição dos Estados signatários, "ainda que esta arbitragem deva verificar-se num país diferente daquele a cuja jurisdição está sujeita qualquer das partes do contrato (art. $1 .^{\circ}$, caput) ; b) instituição da lei eleita pelas partes e lei da sede do tribunal arbitral, nessa ordem, para regular o processo da arbitragem, inclusive a constituição do tribunal (art. $2 .^{\circ}$, caput) ; c) garantia da execução do laudo arbitral proferido no território dos Estados parte do Protocolo (art. 3. ${ }^{\circ}$; d) a remessa ao julgamento dos árbitros, pelos Tribunais dos Estados contratantes, de litígios que envolvam um contrato "que encerre um compromisso ou uma cláusula

29. STF, Apelação Cível ne 9.587, in Revista de Direito Administrativo, v. 34,1953, p. 106.

30. O Brasil, na ratificação do Protocolo, apresentou reserva, no sentido de considerar o compromisso ou cláusula compromissória previstos no art. $1 .^{\circ}$, aplicável "somente aos contratos considerados como comerciais pela lei brasileira" (HILdebrando Accioly, Actos Internacionaes Vigentes no Brasil, 2.", Rio de Janeiro, Irmãos Pongetti, ed., 1936, tomo I, p. 30). 
compromissória", no caso de serem estes válidos ("não haverem caducado ou deixado de produzir efeito" art." e par.).

Nos domínios do direito privado, no período do entreguerras, há um grande movimento de uniformização dos direitos internos dos Estados, relembrando-se que o Direito Uniforme é considerado um instrumento de soluções pacíficas de controvérsias, suprimindo as divergências entre as legislações. Destaque-se a assinatura das Convenções de Genebra de 7 de junho de 1930 (para adoção de uma lei uniforme sobre letras de câmbio e notas promissórias, para regular conflitos de leis em matéria de câmbio e notas promissórias e relativa ao imposto de selo em matéria de letras de câmbio e notas promissórias) e de 19 de março de 1931 (Convenção para adoção de uma lei uniforme sobre cheques, para regular conflitos de leis em matérias de cheques e para regular o imposto de selo em matéria de cheques). As Convenções aprovadas sob a égide da OIT realizam tarefa importante no campo de uniformização de normas trabalhistas.

No continente americano, é intensa a atividade da União Panamericana, criada no final do século anterior, em Washington, em 1889, e que seria posteriormente transformada na atual Organização dos Estados Americanos. No período considerado, adota-se seu texto constitucional em 1928, em Havana, bem como assinam-se os principais tratados que constituem o sistema interamericano atual: asilo político (Montevidéu, 1933) unificação do direito internacional privado, Código Bustamante (Havana, 1928), arbitragem (Montevidéu, 1940) Em 1933, na Sétima Conferência Internacional dos Estados Americanos, foi criada a Comissão Interamericana de Arbitragem Comercial (CIAC), com a "finalidade de estabelecer e manter um sistema interamericano de conciliação e arbitragem para soluções de controvérsias comerciais ${ }^{31}$,

31. C. A. DUnshee DE ABRAnches, Arbitragem Comercial, Aperfeiçoamento, Institucionalização e Universalização, in Sindicato dos Bancos do Estado da Guanabara, Caderno Especial n.o 73 (Juridico n.o 5), p. 13. 
que, na verdade, ficaria sem muita atividade, até 1968, quando se aprovariam seus Estatutos, na Segunda Conferência Interamericana sobre Arbitragem Comercial (México). Ainda quanto à arbitragem entre Estados, é mister fazer-se referência ao Tratado Geral de Arbitramento Interamericano de 1929, adotado por ocasião da Conferência de Conciliação e Arbitragem, reunida em Washington.

No Brasil, aos princípios constitucionais da obrigatoriedade de recurso à arbitragem internacional para a solução de disputas entre Estados (Const. de 1891 art. 34 e 88 e Cont. de 1934 art. $4 .^{\circ}$ ), o art. $5^{\circ}$, xIx, letra c, da Constituição Federal de 1934 dava competência à União de legislar sobre "normas fundamentais da arbitragem comercial" e, no par. 3.0 do mesmo artigo, dava competência concorrente aos Estadosmembros para "atendendo às peculiaridades locais, suprir as lacunas ou exigências da legislação federal, sem dispensar as exigências desta" 32. Foi em obediência aos princípios constitucionais que o Brasil, no período considerado, assinou Convençōes de arbitragem com todos os países vizinhos.

O sistema da Liga das Nações funcionaria até a eclosão da Segunda Guerra Mundial. Embora não caiba aqui uma apreciação das causas do conflito de 1939/1945, bastaria apontar que o sistema de segurança coletiva ilimitada, onde a unanimidade entre Estados é a regra, não poderia funcionar a contento, num ambiente internacional onde impera uma igualdade jurídica, mas profundas desigualdades políticas. Por outro lado, em nenhum momento os grandes Estados estiveram ao mesmo tempo, presentes na Liga das Nações, o que impediu que ela servisse de verdadeiro canal diplomático e de órgão de soluções pacíficas de litígios entre seus Membros; os EUA nunca foram membros (pela paradoxal recusa do Se-

32. Esta é a única vez que a expressão arbitragem comercial aparece em um texto constitucional brasileiro. A Constituiçāo Federal de 1937, art. 18 letra g, criava competência concorrente para os Estados legislarem sobre "processo judicial e extra-judicial". Em todas as Constituiçóes, salvo a do Império, há referências expressas à arbitragem, como meio de evitar-se a guerra. 
nado norte-americano de aprovar a parte dos Tratados de Versalhes que consagravam o ideal do Presidente Wilson), a Alemanha quando admitida, não encontraria a uRss, que tinha sido expulsa, pela sua invasão na Finlândia.

$\mathrm{O}$ sistema que se seguiu, atualmente em vigor, se caracteriza pelo estabelecimento de um mecanismo de segurança coletivo, pelo qual são imediatamente responsáveis, portanto com direito de paralisar o funcionamento do organismo (direito de veto no Conselho de Segurança) as cinco maiores potências, membros permanentes do Conselho de Segurança: EuA, urss, França, Grã-Bretanha e República Popular da China. E a partir de 1945, que mais se evidencia o espírito federalizante da história atual, com a criação de inumeráveis organismos internacionais, ao lado da onU.

A ONU aperfeiçoou o sistema da Liga ao colocar o tribunal internacional, agora com a nova denominação de Corte Internacional de Justiça, como seu órgão, ao lado dos demais: Assembléia Geral, Conselho de Segurança, Conselho de Tutela e Conselho Econômico e Social (ECOsOc). Através do Ecosoc, vinculou a si os organismos internacionais anteriormente existentes (UPU, ITU, OIT), criou outros mais (FAO, OACI, UNESCO, etc.) e trouxe para sua coordenação os inúmeros organismos internacionais não governamentais (NGOS), tais como a Cruz Vermelha Internacional, a International Law Association, etc. O Secretário Geral da onu passa a ser, por excelência e devido ao seu prestígio, mediador e conciliador, com a faculdade de chamar a atenção, ex officio, do Conselho de Segurança para as situações em que haja ameaça à paz mundial.

$\mathbf{E}$, ainda na atualidade, que se viu aparecerem os organismos regionais de segurança coletiva, que, de certa forma, concorrem com a ONU na busca de solução de conflitos entre os participanates: NATO, Pacto de Varsóvia, etc. A antiga União Panamericana muda sua denominação para Organização dos Estados Americanos, OEA, e busca modernizar sua estrutura e funcionamento. 
A maior contribuição para as soluçōes pacíficas de litígios entre Estados, se dá no campo da cooperação econômica regional. Criam-se organismos de integração econômica regional, que vão do tipo "zona de livre comércio" (ALALC, EFTA), até os esquemas de maior integração econômica, do tipo mercado comum (união alfandegária com instituições comunitárias e uma política econômica e comercial comum), Mercado Comum Centro-Americano, Comunidades Econômicas Européias (MCE), Conselho de Assistência Mútua (COMECON). Nas Comunidades Econômicas Européias aparece a Corte de Justiça Européia, que funciona como tribunal europeu das três Comunidades, CECA, CEE e EURATOM, e cuja jurisprudência é da mais alta relevância para as soluções de controvérsias entre os integrantes das Comunidades européias e exemplo vivo das soluções justiciáveis de litígios entre Estados.

E ainda no período histórico em consideração, que, pela primeira vez na vida internacional, se procura disciplinar o comércio entre as Nações. Formas de controlar os meios de pagamentos internacionais são elaborados no seio do FMI e nos mecanismos de financiamentos internacionais, através de um banco mundial, BIRD, cujas ações buscam "despolitizar" o mundo das finanças públicas internacionais. Mais diretamente, a constituição do GATT e as realizações das conferências sobre comércio e desenvolvimento, UNCTAD, buscam disciplinar o comércio, seja propiciando à multilateralização de cláusulas de nações mais favorecidas, seja influindo, diretamente, nas condições em que se realiza o comércio internacional.

Quanto às arbitragens entre particulares, seu interesse multiplicou, especialmente a partir de 1950, devido à maior frequiência de contratos comerciais internacionais (compra e venda, transferência de tecnologia) e do movimento internacional de inversões de capital privado ou estatal. Convenções multilaterais (de Nova York de 1958, Convenção Européia 
sobre Arbitragem Internacional, Genebra, 1961), maior frequiência de cláusulas arbitrais em tratados de comércio e navegação, em favor de particulares dos Estados contratantes ${ }^{33}$, o aparecimento de inúmeras instituições permanentes arbitrais (a ONU recenseou 127 existentes) de vocação universal, tais como a Corte Arbitral da Câmara de Comércio Internacional de Paris, a American Arbitration Association, as Cortes Arbitrais das Câmaras de Comércio de Londres, Genebra, Estocolmo e do Ministério do Comércio Exterior da URSs, são manifestações inequívocas da importância da arbitragem internacional entre particulares. Por outro lado, a praxe do comércio internacional tornou obrigatório o uso de cláusulas arbitrais em todos os negócios comerciais transnacionais, especialmente aqueles que envolvem figuras jurídicas relativamente recentes, como as concessões minerárias, petrolíferas, de serviços públicos, e ainda os contratos ou tratados de transferência de tecnologia ou de transferência direta de investimentos. Os temores das nacionalizações de investimentos diretos ou indiretos, a busca de soluções extrajudiciais mais expeditas e concordes com a natureza dos negócios, inclusive pelo seu segredo, fizeram da arbitragem comercial internacional o meio mais adequado para solucionar pendências. Ressalte-se, sobremaneira, ser a arbitragem o único instrumento que pode conciliar o fato de os Estados estarem cada vez mais a praticarem o comércio, com a regra universalmente aceita de que "par in parem non habet judicium"; na verdade, a jurisdição contratual pode solucionar as questões de imunidades de jurisdição dos Estados, ressalvando sua dignidade de ser soberano, insusceptível de submissão à jurisdição estatal de outro Estado, mesmo quando praticam atos de gestão ${ }^{34}$.

33. A doutrina anglo-norte-americana denomina semelhantes tratados, que contêm cláusulas compromissórias de que se podem valer os particulares, "umbrella treaties". São freqüentes na prática de comércio com os paises do Leste Europeu.

34. A distinção entre "acta jure imperti" e "acta jure gestionis" é uma verdadeira "vexata quæstio", não resolvida pelo Direito Internacional Público. 
A Convenção de Nova York de 10 de junho de 1958, "para o reconhecimento e a execução de sentenças arbitrais estrangeiras" ${ }^{35}$, à qual o Brasil não aderiu até a presente data, entrou em vigor a 7 de junho de 1959. Do Continente americano, são partes: Cuba, Estados Unidos da América, Equador, México, Trinidad e Tobago; ainda não ratificaram, embora signatários, Costa Rica e República Argentina. No total, é vigente entre 50 Estados, na maioria europeus (exclusive a Grã-Bretanha) ${ }^{36}$. Por força do art. viı, § 2. ${ }^{\circ}$, a Convenção de Nova York substitui e revoga os anteriores Protocolo de Genebra de 1923, relativo a cláusulas arbitrais e à Convenção de Genebra de 1927 para a execução de sentenças arbitrais estrangeiras. Dada a importância do documento, em apêndice, transcrita está a Convenção de Nova York, em tradução livre do autor.

No Continente americano, a Comissão Interamericana de Arbitragem Comercial (CIAC), a Segunda Conferência Interamericana de Arbitragem Comercial, adota seus Estatutos (México, 1968) : é ela "integrada pelas Seções Nacionais já constituídas ou que vierem a se constituir em cada um dos Estados Americanos. . e nos países em que não se conclui ainda a organização da Seção local da cisc, são utilizados os serviços das Câmaras de Comércio e dos Colégios de Abogados ${ }^{37}$. A seção brasileira da CIAc é o Centro Brasileiro de Albitragem, fundado em 1967, com sede no Rio de Janeiro, cujos objetivos são: "I - propugnar pelo aperfeiçoamento do

35. Na termínologia do direito brasileiro, "reconnaissance des sentences", "recognition of foreign judgments or arbitral awards", se traduzem por homologação das sentenças, homologação de sentenças estrangeiras ou de laudos arbitrais. Preferimos, contudo, o termo reconhecimento, pois ficaria impossível traduzir o art. 3.0 da citada Convenção de Nova York, cujo texto, em francês, estatui: "Chacun des Etats contractantes reconnaitra l'autorité d'une sentence arbitrale..."

36. Informações retiradas do "Report of the Vice President of the Inter american Commercial Arbitration Commission, Donald B. Straus" na VI Conferência Interamericana sobre Arbitragens Comerciais, realizada no Rio de Janeiro, em $5 / 6$ de abril de 1976, p. 4.

37. C. A. DUnshee de Abranches, op. cit., p. 13/14. 
instituto da arbitragem em todos os campos do Direito; II colaborar com os poderes públicos, instituições culturais e associações profissionais nas matérias relacionadas com os objetivos do CBA; III - servir como organização destinada a facilitar a aplicação das normas substantivas e adjetivas da arbitragem para a solução de controvérsias ou reclamação cível, comercial, trabalhista ou de qualquer natureza, permitida pelo direito aplicável em cada caso; IV - exercer no Brasil, as funções atribuídas às Seções Nacionais pelos Estatutos e atos constitutivos da CIAC, criada em 1933, por Resolução da VII Conferência dos Estados Americanos, em Montevidéu ${ }^{38}$. A ciAc mantém convênio "com a Associação Japonesa de Arbitragem Comercial, com sede em Tóquio, para a cooperação entre as duas organizações, no caso de uma controvérsia entre uma parte domiciliada em um país americano e outra domiciliada no Japão ${ }^{39}$. Segundo Fouchard, que cita fontes do Arbitration Journal ${ }^{40}$, a cIAC tem importante atividade, tendo registrado em 1949, 92 pedidos novos de arbitragem, procedido a 155 resoluções de litígios, num total de $250 \mathrm{mil}$ dólares. São seções ativas da CIAC: a American Arbitration Association (AAA), norte americana, e as seções do México, Chile, Argentina, Colômbia, Venezuela, Equador, Peru, Panamá, Costa Rica e Guatemala.

Em 30 de janeiro de 1975, na Conferência Especializada Interamericana sobre Direito Internacional Privado, no Panamá, assinaram a Convenção Interamericana sobre Arbitragem Comercial Internacional, delegados de doze países, inclusive o Brasil, destacando-se a participação efetiva dos EUA, sempre relutantes em subscreverem atos internacionais que impliquem na transformação de seu direito privado interno. Rezam os principais artigos da Convenção do Panamá de 1975: Art. $10^{\circ}-$ E válido o acordo das partes em virtude

38. C. A. DUnshee de Abranches, op. cit. p. 11.

39. C. A. DUNSheE de ABranches, op. cit., p. 15.

40. Painippe Fodchard, L'Arbitrage Commercial International, Paris, Lib. Dalloz, 1965, p. 213, rodapé 22. 
do qual se obrigam a submeter à decisão arbitral as divergências que possam surgir ou que hajam surgido entre elas com relação a um negócio mercantil. $\mathrm{O}$ respectivo acordo constará de documento assinado pelas partes, ou de troca de cartas, telegramas ou comunicações por telex. Art. $2 .^{\circ}-\mathrm{A}$ nomeação dos árbitros será feita na forma em que convierem às partes. Sua designação poderá ser delegada a um terceiro, seja este pessoa física ou jurídica. Os árbitros poderão ser nacionais ou estrangeiros. Art. $30^{\circ}-\mathrm{Na}$ falta de acordo expresso entre as partes, a arbitragem será efetuada de acordo com as normas de procedimento da Comissão Interamericana de $\mathrm{Ar}$ bitragem Comercial ${ }^{41}$. Dos signatários, consta ter ratificado a Convenção tão somente o Panamá, até a presente data.

Enfim, faz-se mister uma referência, ainda que superficial, ao novíssimo campo em que se tem verificado arbitragens, com soluções absolutamente inovadoras, tanto para a técnica das arbitragens comerciais internacionais, quanto para a própria teoria do Direito Internacional Público e Privado. Apareceu no mundo dos negócios internacionais, uma zona cinzenta, entre as esferas do direito público e privado e interno e internacional, curiosamente assimilável à situação da arbitragem na Idade Média, onde se verifica a necessidade de arbitragens para solucionar conflitos entre Estados, de um lado, e de outro, poderosíssimos grupos econômicos privados, as emprêsas multinacionais, cujo ecumenismo faz recordar a "unidade na universalidade" da Igreja Católica medieval ou do Sacro Império Romano Germânico. Tem acontecido casos, o mais famoso é o da sentença arbitral entre o Governo da Arábia Saudita e a Arabian American Oil Company (Caso ARANCo, sentença de 23 de agosto de 1958, tribunal composto de dois egípcios e presidido pelo suíço Sausser-HaLl, com sede em Genebra), em que os tribunais arbitrais têm aplicado normas de Direito Internacional Público, a contratos passados entre Estados e aquelas empresas multinacionais.

41. C. A. Dunshee de Abranches, op. cit., p. 16. 
Ora, inexistia no Direito Internacional Público capítulo referente a contrato entre Estado e particular, assim como inexistiam na Teoria Geral do Direito Internacional Privado regras de qualificação de negócios entre semelhantes pessoas, relativas, a exemplo, a concessões minerárias, petrolíferas ou de serviços públicos. São, exatamente, os precedentes dos laudos arbitrais que têm enriquecido tais campos novos de estudos, que desfazem a tradicional divisão entre Direito Internacional Público e Direito Internacional Privado, apontando para possíveis soluções no controle da ação das multinacionais.

A tal ponto a influência das inversōes diretas de capital de grupos privados, multinacionais, não tipificáveis, se impôs, que a própria Assembléia Geral da onU, por Resolução, aprovaria, por proposta do Banco Internacional de Reconstrução e Desenvolvimento, uma "Convenção sobre Resolução de Controvérsias Relativas a Inversões entre Estados e Particulares", conhecida como Convenção BIRD, de 1965, atualmente em vigor ${ }^{42}$ para os Estados signatários, dentre os quais não se encontra nenhum país da América Latina ${ }^{43}$. Registrada sob n. ${ }^{\circ} 8.359$ no Recueil des Traités da onv, a Convenção BIRD cria um Centro Internacional para Solução de Disputas

42. O art. $68 \S 2.0$ dispõe que o convênio entrará em vigor 30 dias após o depósito do vigésimo instrumento de ratificação, aceitação ou aprovação. Segundo informação do Dr. Juan Andres Lliteras, no informe "El arbitrage Internacional entre Estados y Particulares", apresentado na VI Conferência Interamericana sobre Arbitragem Comercial, Rio de Janeiro, 1976, até a data, 65 Estados teriam ratificado a Convenção BIRD, (p. 5).

43. Sem embargo das observaçôes do Dr. Lliteras (vide nota anterior) de que a falta de países da América Latina na Convenção BIRD se explicaria por estarem tais paises mais familiarizados com cláusulas arbitrais da OEA do que as votadas na ONU e prefiram, pois, utilizar cláusulas e tribunais da CIC ou da CIAC, a razão parece ser bem outra. "Contudo, os pafses latinoamericanos, que têm tradicionalmente resistido a qualquer resolução internacional de disputas sobre investimentos, insistindo, ao invés disso, em que os investidores se submetam exclusivamente à jurisdição local, sob a denominada cláusula Calvo, têm recusado ratificar a convenção (Carl H. Fulda e Warren F. Schwartz, Regulation of International Trade and Investment, Cases and Materials, Mineola, Nova York, The Foundation Press, Inc., 1970, p. 704, em tradução livre do autor). A cláusula Calvo diz respeito à renúncia contratual da proteção diplomática, nas concessōes (que os EUA nunca aceitaram, por acharem que o direito à proteção diplomática pertence ao Estado, sendo irrenunciável). 
sobre Inversões, que tem como objetivo, "facilitar a submissão de controvérsias relativas a inversões entre Estados contratantes a um procedimento de conciliação e arbitragem, de acordo com a disposição da Convenção (art. 11, § 2. ${ }^{\circ}$ ). No seu preâmbulo lê-se que "ainda quando tais discordâncias se submetam correntemente a sistemas processuais nacionais, em certos casos, o emprego de métodos internacionais de acerto pode ser apropriado para sua solução". Reconhece, ainda na cláusula 4 a. do preâmbulo, que atribui "particular importância à disponibilidade de meios de conciliação ou arbitragem internacionais a que os Estados contratantes e os nacionais dos Estados contratantes possam, se o quiserem, submeter seus litígios". Com 75 artigos, a Convenção BIRD dispõe no Capítulo I, sobre o Centro Internacional de Solução de Controvérsias relativas a inversões; no Cap. II, sobre a jurisdição do Centro ${ }^{44}$, no III, sobre a conciliação (solicitação, constituição da comissão de conciliação, procedimento de conciliação), no IV, da arbitragem (solicitação, constituição do tribunal, suas faculdades e funções, do laudo, sua interpretação, revisão ou anulação e homologação e execução do laudo; no $\mathrm{V}$, sobre a substituição e recusa de conciliadores e árbitros no VI, custas do procedimento; no VII, lugar do procedimento; no VIII, divergências de interpretação da Convenção BIRD entre os Estados contratantes (falhado o recurso da negociação diplomática, as partes devem recorrer à Corte Internacional de Justiça, para interpretação ou aplicação da Convenção, art. 64) ${ }^{45}$; no IX, emendas e no X, dis-

44. Estatui o art. 25, $\S 2 .^{\circ}$ (b), para os efeitos de determinar a jurisdição do Centro, no que respeita à nacional do outro Estado contratante, "toda pessoa jurídica que, na data em que as partes prestaram seu consentimento à jurisdição do Centro para o litígio em questão, tenha a nacionalidade de um Estado contratante distinto do Estado parte no litígio, e as pessoas jurídicas que tendo na referida data a nacionalidade do Estado parte no litígio, tenham as partes concordađo em atribuir-lhe tal caráter, para efeitos deste Convênio, por estarem submetidas a controle estrangeiro".

45. O art. $41 \S 1 .^{\circ}$ incorpora o principio vigente em arbitragem internacional de que "o tribunal resolvera sobre sua própria competência", em matéria prévia ou de fundo, a seu juízo. Ora, o recurso à CIJ, em matéria de interpretação da Convenção BIRD, anularia semelhante disposição, que se basela na autonomia da cláusula compromissória. 
posições finais. De certa forma resguardando a superioridade do Estado em relação aos nacionais de outro Estado, o art. 42 dispõe que o Tribunal arbitral constituído sob a égide do Centro "decidirá o litígio de acôrdo com as normas de direito acordadas entre as partes. À falta de acordo, o Tribunal aplicará a legislação do Estado que seja parte no litígio, incluindo suas normas de direito internacional privado e aquelas normas de direito internacional que puderem ser aplicadas". No mesmo art. 42 , há a proibição de recusar-se o julgamento a pretexto de lacuna ou obscuridade da lei $\left(\$ 20^{\circ}\right)$ e a possibilidade de decisão "ex aequo et bono", "se as partes assim acordarem $\left(\$ 3 .^{\circ}\right)$. Ve-se, dessa forma, a conciliação e a arbitragem com roupagem nova, a solucionar questões das mais atuais, quais sejam os problemas suscitados pela atuação de entidades transnacionais que, em determinados casos, ombreiam com os Estados, ou ultrapassam-nos, em matérias de volumes de recursos carreados nas relações comerciais internacionais, com uma força e poderes de decisão do ponto-devista político, em condições extremamente desiguais e conflitantes.

Finalmente, algumas palavras sobre o ensino, no Brasil, de tão importante disciplina. Segundo é do conhecimento do autor, na presente data, salvo nos raros Cursos de Graduação que ainda mantém a disciplina Direito Internacional Público, a matéria é ministrada como um dos muitos capítulos da mesma. Unicamente a Faculdade de Direito da Universidade de São Paulo, no curso de especialização (antigo 5. ano), no $\mathrm{X}$ semestre, mantém a disciplina "Técnica das $\mathrm{Ne}$ gociações, das Arbitragens e das Soluções Pacíficas de Controvérsias", ministradas nas áreas I (Direito Político, Administrativo e Financeiro), III (Direito Privado e Processual Civil), IV (Direito de Empresa-Administração Empresaiial e Tributária) e V (Direito do Trabalho e Segurança Social), com programas ligeiramente diferenciados para cada qual, em função da ênfase que a disciplina requer para cada área, mas buscando-se conservar uma unidade de 
direito público e privado internacionais, como é de exigir-se para o seu estudo na atualidade. Em reunião do Departamento de Direito Internacional de 30 de março de 1976, decidiu-se incluir o tema de arbitragens internacionais no rol das matérias que deverão integrar os pontos a serem sorteados, na prova escrita e na aula pública, nos futuros concursos para obtenção dos títulos de doutor, ou de livre-docente, tanto em Direito Internacional Público, como em Direito Internacional Privado, pois julgou-se que o tema pertence a ambos os ramos do Direito, sendo de fundamental importância na bagagem intelectual de qualquer estudioso do Direito Internacional, nos dias que correm.

Aí estão, pacientemente elaborados pela história do homem, os instrumentos para as soluções pacíficas de litígios. Se tais instrumentos conseguirão solucionar as controvérsias, pacificar as relações humanas e, sobretudo, realizar a justiça entre os povos, nos tempos que hão de vir, não é questão a ser respondida pelos estudiosos do Direito Internacional. Estes estão cientes de que, se a norma fôr violada, um valor foi desprezado e não é a existência de uma sanção centralmente organizada que irá definir aquele valor. $\mathrm{O}$ que se busca no Direito Internacional, principalmente no capítulo das soluções pacíficas de litígios, é, com primazia, evitar o confronto da força bélica, negação do espírito, e as soluções pacíficas são frutos da afirmação do espírito, porque elaboradas na história do homem, para preservação da vida e de sua criatividade.

Convenção para a homologação e execução de laudos arbitrais estrangeiros, assinada em New York, em 10 de junho de 1958 1.

\section{Artigo I.}

1 A presente Convenção se aplica à homologação ${ }^{2} \mathrm{e}$ à execução de laudos arbitrais prolatados no território de um

1. Tradução livre do autor, segundo o texto em francês, publicado em Philippe Fouchard, L'Arbitrage Commercial International, Paris, Lib. Dalloz, 1965 (apêndice, p. 547/551).

2. Veja-se nota de rodapé $n^{\circ} 35$ do artigo de referência. Reconnaissance 
Estado outro que aquele onde a homologação e a execução dos laudos são pedidas, e originadas de controvérsias entre pessoas físicas ou jurídicas. Aplica-se, igualmente, a laudos arbitrais que não são considerados como laudos nacionais no Estado onde sua homologação e execução são pedidas.

2. Entende-se por "laudo arbitral" 3 , não somente os laudos prolatados por árbitros nomeados para casos determinados, mas igualmente, os pronunciados por órgãos permanentes de arbitragem aos quais as partes se submeteram.

3. No momento de assinar ou de ratificar a presente Convenção, de a ela aderir ou de fazer a notificação de extenção prevista no artigo X, qualquer Estado poderá, na base daa reciprocidade, declarar que aplicará a Convenção à homologação e execução dos laudos unicamente proferidos no território de outro Estado contratante. Poderá, igualmente, declarar que aplicará a Convenção unicamente nas controvérsias oriundas de relações jurídicas, contratuais ou não contratuais, que são consideradas como comerciais pela sua lei nacional.

\section{Artigo II.}

1 Cada Estado contratante reconhece a convenção escrita pela qual as partes se obrigam a submeter a uma arbitragem todas as controvérsias ou determinadas controvérsias que tenham surgido ou que venham a surgir entre elas, a respeito de uma relação jurídica determinada, contratual ou não contratual, relacionadas com uma questão suscetível de ser resolvida pela via arbitral.

2. Entende-se por "convenção escrita" uma cláusula compromissória inserida num contrato, ou um compromisso,

des sentences arbitrales será traduzido por homologação de laudo arbitral (terminologia do vigente CPC), sempre que possivel.

3. No original, entre aspas, sentences arbitrales. 
assinado pelas partes ou contido numa troca de cartas ou de telegramas.

3. O tribunal de um Estado contratante, perante o qual esteja pendente um litígio sobre uma questão a respeito da qual as partes concluiram uma convenção no sentido do presente artigo, remeterá as partes ao julgamento dos árbitros, a pedido de uma delas, a menos que ele constate que a mencionada convenção haja caducado, seja inoperante ou insuscetível de ser aplicada.

\section{Artigo III.}

Cada Estado contratante reconhecerá a autoridade de uma sentença arbitral e garantirá a execução ${ }^{4}$ dessa sentença, conforme as regras processuais adotadas no território onde a sentença é invocada, nas condições dos artigos seguintes. Não serão impostas, para a homologação ou execução de laudos arbitrais aos quais se aplica a presente Convenção, condições sensivelmente mais rigorosas, nem custas judiciais sensivelmente mais elevadas, que aquelas impostas para a homologação ou execução de laudos arbitrais nacionais.

\section{Artigo IV.}

1 Para obter a homologação e a execução contempladas no artigo precedente, a parte que solicita a homologação e a execução deve apresentar, ao mesmo tempo em que faz o pedido:

a) o original, devidamente autenticado, do laudo ou uma cópia de tal original, que reúna condições requeridas para sua autenticidade;

b) o original da convenção contemplada no artigo II, ou uma cópia que reúna condiçōes requeridas para sua autenticidade.

4. accordera l'execution. 
2. Se o citado laudo ou a citada convenção não estiverem redigidos em língua oficial do país onde o laudo é invocado, a parte que pede a homologação ou a execução do laudo, deverá providenciar uma tradução daqueles documentos, naquela língua. A tradução deverá ser reconhecida por um tradutor oficial, ou um tradutor juramentado ou um agente diplomático ou consular.

\section{Artigo V.}

1. A homologação e a execução do laudo somente serão recusadas, a pedido da parte contra a qual este é invocado, se esta parte produzir perante a autoridade do país onde a homologação e a execução são solicitadas, a prova de que:

a) as partes na convenção mencionada no artigo II, eram, em virtude da lei a elas aplicável, incapazes, ou que a citada convenção não é válida, segundo a lei à qual as partes a submeteram, ou, na falta de uma indicação a tal respeito, em virtude da lei do país onde o laudo foi proferido; ou

b) a parte contra a qual o laudo é invocado, não foi suficientemente informada sobre a designação do árbitro ou sobre o processo de arbitragem, ou que lhe fora impossível, por qualquer outra razão, de fazer valer seus direitos; ou

c) que o laudo se refere a uma controvérsia não estabelecida no compromisso ou que não trata das questões previstas na cláusula compromissória, ou que contém decisões que ultrapassam os termos do compromisso ou da cláusula compromissória: contudo, se as disposições do laudo que se relacionam a questões submetidas à arbitragem podem ser dissociadas de questões não submetidas à arbitragem, as primeiras poderão ser homologadas e executadas; ou

d) a constituição do tribunal arbitral ou do procedimento de arbitragem não foi conforme à convenção das partes ou, na falta de convenção, que ela não foi conforme à lei do país onde a arbitragem teve lugar; ou 
e) o laudo ainda não se tornou obrigatório para as partes ou foi anulado ou suspenso por alguma autoridade competente do país no qual, ou segundo cuja lei, o laudo foi proferido.

2. A homologação e a execução de um laudo arbitral poderão também ser recusadas, se a autoridade competente do país onde a homologação e a execução são requeridas constatar:

a) que, segundo a lei desse país, o objeto da controvérsia não é suscetível de ser submetido à arbitragem;

b) que a homologação ou a execução do laudo são contrárias à ordem pública desse país.

\section{Artigo VI.}

Se a anulação ou suspensão do laudo são pedidos à autoridade competente mencionada no artigo $\mathrm{V}$, parágrafo $1 .^{\circ}, \mathrm{e}$, a autoridade perante quem o laudo é invocado pode, se esta o estime apropriado, adiar pronunciar-se sobre a execução do laudo; pode, igualmente, a pedido da parte que pede a execução da sentença, ordenar à outra parte apresentar garantias apropriadas.

\section{Artigo VII.}

1. As disposições da presente Convenção não atingem a validade de acordos multilaterais ou bilaterais concluídos pelos Estados contratantes, em matéria de homologação e de execução de laudos arbitrais e não privam qualquer parte interessada do direito que poderia ter de prevalecer-se de um laudo arbitral, da maneira e na medida admitidas pela legislação ou os tratados do país onde o laudo é invocado.

2. O Protocolo de Genebra de 1923, relativo a cláusulas de arbitragem e a Convenção de Genebra de 1927, para a execução de laudos arbitrais estrangeiros, cessarão de produzir efeitos entre os Estados contratantes, no dia e na medida em que estes tornarem-se partes na presente Convenção. 


\section{Artigo VIII.}

1. A presente Convenção fica aberta até 31 de dezembro de 1958 à assinatura de qualquer Estado membro das Nações Unidas, bem como de qualquer outro Estado que é, ou que em seguida se torne, membro de uma ou de várias instituições especializadas das Nações Unidas ou parte no Estatuto da Corte Internacional de Justiça ou que tenha sido convidado pela Assembléia Geral das Nações Unidas.

2. A presente Convenção deverá ser ratificada e os instrumentos de ratificação depositados junto ao Secretário Geral da Organização das Nações Unidas.

\section{Artigo IX.}

1 Todos os Estados mencionados no artigo VIII podem aderir à presente Convenção.

2 A adesão se fará pelo depósito de um instrumento de adesão junto ao Secretário Geral da Organização das Nações Unidas.

\section{Artigo X.}

1 Qualquer Estado poderá, no momento da assinatufará por notificação dirigida ao Secretário-Geral da Organivenção se estenderá ao conjunto de territórios que representa no plano internacional, ou a um ou vários dentre eles. Tal declaração produzirá efeitos no momento da entrada em vigor da Convenção para o citado Estado.

2. Em seguida, qualquer extensão de tal natureza se fará por notificação dirigida ao Secretário Geral da Organização das Nações Unidas e produzirá efeitos a partir do nonagésimo dia que se seguirá à data na qual o Secretário Geral das Nações Unidas terá recebido a notificação, ou na data de entrada em vigor da Convenção para o citado Estado, se tal data é posterior. 
3. No que respeita aos territórios aos quais a presente Convenção não se aplica na data da assinatura, da ratificação ou da adesão, o Estado interessado examinará a possibilidade de tomar as medidas que desejar, para estender a presente Convenção a tais territórios, sob reserva, se for o caso, do assentimento dos governos de tais territórios, se razões constitucionais o exigirem.

\section{Artigo XI.}

As disposições anteriores aplicar-se-ão aos Estados federativos ou não unitários:

a) no que concerne aos artigos da presente Convenção que dependem da competência legislativa do poder federal, as obrigaçães do Governo federal serão as mesmas que as dos Estados contratantes que não são Estados federativos;

b) no que concerne aos artigos da presente Convenção que dependem da competência legislativa de cada Estado ou províncias constituintes, que não se encontram, em virtude do sistema constitucional da federação, obrigados a tomar medidas legislativas, o governo federal levará, o mais cedo possível, e com sua opinião favorável, os citados artigos ao conhecimento das autoridades competentes dos Estados ou províncias constituintes;

c) um Estado federativo, parte da presente Convenção, comunicará, a pedido de qualquer outro Estado contratante, que lhe será transmitido pelo Secretário-Geral da Organização das Nações Unidas, um enunciado da legislação e das práticas em vigor na federação e suas unidades constituintes, no que respeita tal ou qual disposição da Convenção e indicará a medida na qual foi dada eficácia, por uma ação legislativa ou outra, à citada disposição. 


\section{Artigo XII.}

1. A presente Convenção entrará em vigor no nonagésimo dia que se seguir ao depósito do trigésimo instrumento de ratificação ou de adesão.

2. Para qualquer dos Estados que ratificarem a Convenção ou a ela aderirem após o depósito do trigésimo instrumento de ratificação ou de adesão, entrará em vigor no nonagésimo dia que se seguir ao depósito por este Estado de seu instrumento de ratificação ou de adesão.

\section{Artigo XIII.}

1. Qualquer Estado contratante poderá denunciar a presente Convenção através de notificação escrita endereçada ao Secretário-Geral da Organização das Naçōes Unidas. A denúncia produzirá efeito um ano após a data em que o Secretário-Geral da Organização das Nações Unidas houver recebido a notificação.

2. Qualquer Estado que houver feito uma declaração ou notificação conforme $\mathrm{o}$ artigo $\mathrm{X}$ poderá notificar, ulteriormente, o Secretário-Geral da Organização das Nações Unidas de que a Convenção cessará de aplicar-se ao território em questão, um ano após a data em que o Secretário-Geral houver recebido tal notificação.

3. A presente Convenção continuará a ser aplicada aos laudos arbitrais sobre as quais um processo de homologação ou de execução tiver sido iniciado antes da entrada em vigor da denúncia.

\section{Artigo XIV.}

Um Estado contratante não pode reclamar das disposições da presente Convenção contra outros Estados contratantes senão na medida em que ele mesmo esteja obrigado a aplicar esta Convenção. 


\section{Artigo XV.}

O Secretário-Geral da Organização das Naçōes Unidas notificará a todos os Estados mencionados no artigo VIII: go VIII;

a) as assinaturas e ratificações mencionadas no arti-

b) as adesões mencionadas no artigo IX;

c) as declarações e notificações mencionadas nos artigos primeiro, $\mathrm{X}$ e XI;

d) a data em que a presente convenção entrar em vigor, conforme aplicação do artigo XII; XIII.

e) as denúncias e notificações mencionadas no artigo

\section{Artigo XVI.}

1. A presente Convenção, cujos textos em inglês, chinês, espanhol, francês e russo fazem igualmente fé, será depositada nos arquivos da Organização das Nações Unidas.

2. O Secretário-Geral da Organização das Nações Unidas remeterá uma cópia certificada da presente Convenção aos Estados mencionados no artigo VIII. 